Architect of Justice 


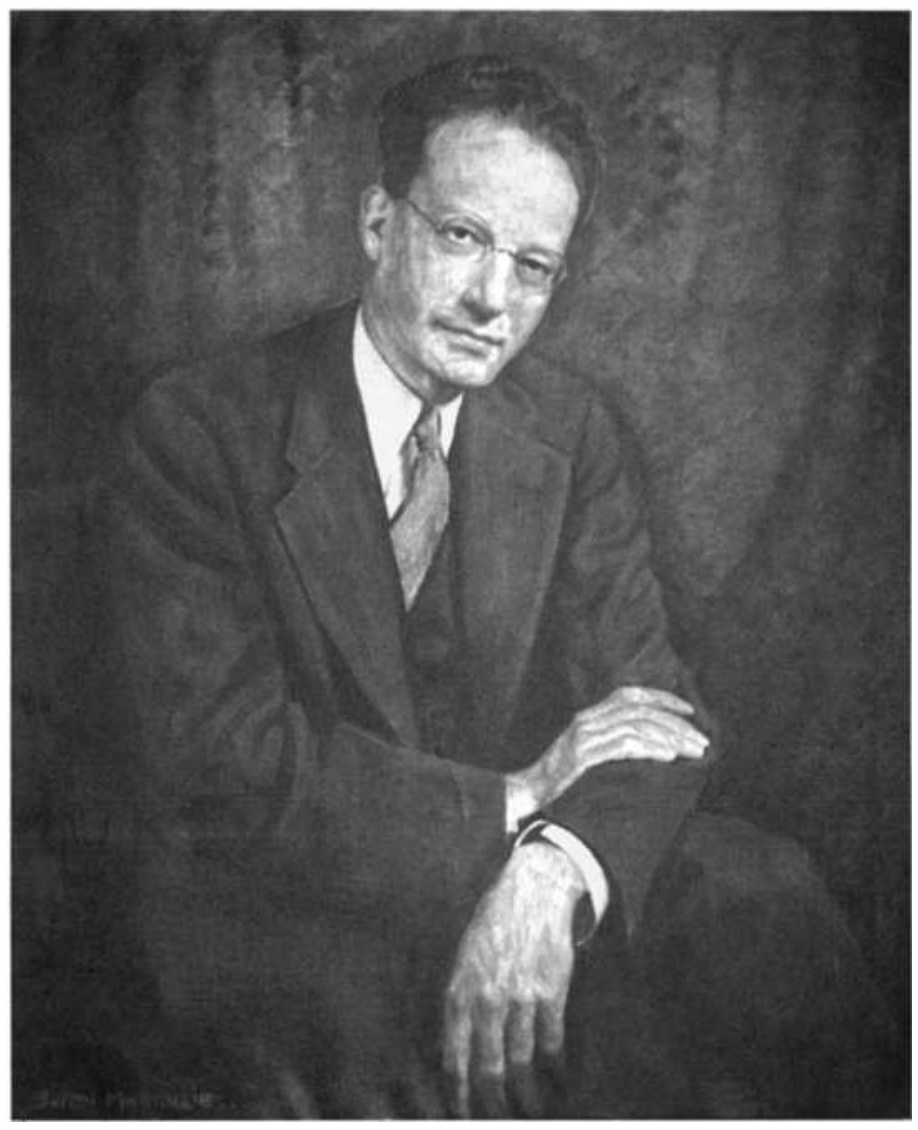




\title{
Architect of Justice
}

\author{
Felix S. Cohen and the Founding \\ of American Legal Pluralism
}

\section{Dalia Tsuk Mitchell}


Frontispiece: Portrait of Felix S. Cohen by Joseph T. Margulies. Used by permission of The City College of New York, CUNY.

\section{Copyright (C) 2007 by Cornell University}

All rights reserved. Except for brief quotations in a review, this book, or parts thereof, must not be reproduced in any form without permission in writing from the publisher. For information, address Cornell University Press, Sage House, 512 East State Street, Ithaca, New York 14850.

First published 2007 by Cornell University Press

Printed in the United States of America

Library of Congress Cataloging-in-Publication Data

Tsuk Mitchell, Dalia.

Architect of justice : Felix S. Cohen and the founding of American legal pluralism / Dalia Tsuk Mitchell.

p. $\mathrm{cm}$.

Includes bibliographical references and index.

ISBN 978-0-8014-3956-8 (cloth : alk. paper)

1. Cohen, Felix S., 1907-1953. 2. Law teachers-United States-Biography. 3. Legal polycentricity-United States. 4. Indians of North America-Legal status, laws, etc. I. Title.

KF373.C6185T78 2007

$340.092-\mathrm{dc} 22$

[B]

2006035655

Cornell University Press strives to use environmentally responsible suppliers and materials to the fullest extent possible in the publishing of its books. Such materials include vegetable-based, low-VOC inks and acid-free papers that are recycled, totally chlorine-free, or partly composed of nonwood fibers. For further information, visit our website at www.cornellpress.cornell.edu.

$\begin{array}{lllllllllll}\text { Cloth printing } & 10 & 9 & 8 & 7 & 6 & 5 & 4 & 3 & 2 & 1\end{array}$ 
For Larry 
This page intentionally left blank 